\title{
PENGEMBANGAN POSBINDU LANSIA DI POSBINDU JERUK DESA CIPAYUNG KECAMATAN CIPUTAT KOTA TANGERANG SELATAN PROPINSI BANTEN
}

\author{
Nunuk Nugrohowati ${ }^{1}$, Gatot Soeryo Koesoemo ${ }^{1}$, dan Kristin Simanjuntak ${ }^{2}$ \\ ${ }^{1}$ Departemen Kesehatan Masyarakat, FK UPN Veteran Jakarta \\ Email: nnugrohowati@gmail.com \\ ${ }^{2}$ Departemen Biokimia, FK UPN Veteran Jakarta \\ Email: kristin_juntak@yahoo.com
}

\begin{abstract}
The increasing life expectancy of increasing the number of elderly people in Indonesia can have positive and negative impacts. The need for empowerment and enhancing the role of the community as well as empowering public and private partnerships, for example Elderly integrated counseling post (Posbindu) who conducts early detection and monitoring of risk factors for non-communicable diseases in an integrated, routine and periodic manner. The development of the Elderly Posbindu in the village of Cipayung, Ciputat sub-district according to the Guidelines, needs to be developed. The formulation and management of the development of the Elderly Posbindu program in Cipayung village, Ciputat District, South Tangerang City. The incomplete Elderly Posbindu Cadre and the completeness of the Posbindu facilities according to the Ministry of Health's instructions encouraged us to develop the elderly Posbindu in Cipayung village, Ciputa District by comparing with the instructions from the Ministry of Health. After discovering the potentials, problems and challenges in the development of Posbindu Elderly in this region, we implemented a plan for the development of the elderly Posbindu Jeruk in the form of meeting the limited posbindu facilities, conducting non-communicable diseases counseling and training cadres in blood sugar level checks. The provision of health service facilities encourages the community to raise awareness of healthy lifestyles, invites the involvement of the elderly community in the health promotion program independently so that they become eager to live a healthy life and life expectancy is increased. Improving the quality of health workers in the context of prevention and increasing counseling in the health sector in the context of handling non-communicable diseases.
\end{abstract}

Keywords: Development; elderly; independent; Integrated Counseling Post

\begin{abstract}
ABSTRAK
Meningkatnya angka harapan hidup menambah jumlah lansia di Indonesia dapat berdampak positif dan negatif. Perlunya pemberdayaan dan peningkatan peran masyarakat serta pemberdayaan kemitraan pemerintah dan swasta, misalnya Posbindu Lansia yang melakukan kegiatan deteksi dini dan pemantauan faktor risiko Penyakit Tidak Menular secara terpadu, rutin, dan periodik. Masih belum terselenggarakannya Posbindu Lansia di desa Cipayung, kecamatan Ciputat sesuai Petunjuk, perlu dibuat pengembangannya. Terumuskannya dan menata laksana pengembangan program Posbindu Lansia di desa Cipayung Kecamatan Ciputat Kota Tangerang Selatan. Belum lengkapnya Kader Posbindu Lansia dan kelengkapan fasilitas posbindu sesuai petunjuk kemenkes mendorong kami melakukan pengembangan posbindu lansia di desa Cipayung Kecamatan Ciputa dengan cara membandingkan dengan syarat petunjuk dari Kemenkes. Setelah ditemukan potensi, permasalahan dan tantangan dalam pengembangan Posbindu Lansia di wilayah ini, kami menerapkan rencana pengembangan posbindu lansia Jeruk berupa pemenuhan fasilitas posbindu yang masih terbatas, mengadakan penyuluhan penyakit tidak menular dan melatih kader dalam pemeriksaan kadar gula darah. Penyediaan sarana pelayanan kesehatan mendorong masyarakat meningkatkan kepedulian pola hidup sehat, mengajak keterlibatan masyarakat lansia pada program sosialisasi kesehatan secara mandiri sehingga kembali bersemangat untuk hidup sehat dan angka harapan hidup menjadi meningkat. Meningkatkan kualitas tenaga kesehatan dalam rangka pencegahan serta peningkatan penyuluhan di bidang kesehatan dalam rangka penanggulangan penyakit tidak menular.
\end{abstract}

Kata Kunci: Rencana Pengembangan, lansia, mandiri, posbindu lansia, Kunjungan lansia

\section{PENDAHULUAN}

\section{Analisis Situasi}

Lanjut usia atau lansia adalah sehat pada usia lanjut yang dapat mempertahankan kondisi fisik dan mental yang optimal serta tetap melakukan aktivitas sosial dan produktif. Proses penuaan 
mengakibatkan terganggunya berbagai organ di dalam tubuh seperti sistem gastro-intestinal, sistem genito-urinaria, sistem endokrin, sistem immunologis, sistem serebrovaskular dan sistem saraf pusat. Bertambahnya populasi lansia menimbulkan permasalahan, terutama penyakit degeneratif hipertensi. Tinggi nya angka hipertensi di Kecamatan Ciputat pada lansia memerlukan usaha untuk menguranginya. Salah satu tempat pelayanan kesehatan yang sedang digalakkan pemerintah bagi lansia adalah pos pembinaan terpadu lansia (posbindu lansia) atau Posbindu Penyakit tidak menular yang merupakan sarana peran serta masyarakat dalam melakukan kegiatan deteksi dini dan pemantauan faktor risiko PTM utama yang dilaksanakan secara terpadu, rutin, dan periodik. Penyelenggaraan posbindu dilakukan melalui program puskesmas dengan melibatkan peran serta para lansia, keluarga, tokoh masyarakat dan organisasi sosial di lingkungan nya. (Erfandi, 2008). Pelayanan usia lanjut untuk wilayah Kecamatan Ciputat dilakukan di dalam gedung, untuk pengobatan dan kegiatan luar gedung melalui Posbindu. Pada tahun 2014 jumlah posbindu yang ada di wilayah Ciputat adalah 18 Posbindu yang menyebar di 4 kelurahan. Dengan jumlah lansia berusia 45-59 tahun sebanyak 11.909 jiwa dan berusia 60+ sebanyak 6073 jiwa, lansia yang dilayani kesehatannya sebanyak 15.913 jiwa $(88,5 \%)$ besar kemungkinan tidak semua lansia dapat terlayani dengan baik.

\section{Permasalahan Mitra}

a. Masih belum terselenggarakannya Posbindu lansia di desa Cipayung wilayah kecamatan Ciputat sesuai dengan Petunjuk Teknis Posbindu Lansia Direktorat Jenderal Pengendalian Penyakit dan Penyehatan Lingkungan Kemnterian Kesehatan RI tahun 2012, padahal sangat diperlukan Posbindu lansia yang melibatkan masyarakat dan swasta, sebagai acuan untuk segera dilakukan pencegahan faktor risiko Penyakit Tidak Menular.

b. Dari penelitian sebelumnya mengenai kunjungan posbindu lansia dapat disimpulkan bahwa tingginya pemanfaatan posbindu lansia berhubungan dengan pendidikan, pengetahuan, sikap, dukungan keluarga, peran petugas kesehatan dan kader serta persepsi kebutuhan dari lansia sendiri atas adanya posbindu lansia. Dari survei awal juga diketahui bahwa lansia yang datang ke posbindu ternyata mayoritas adalah lansia yang sudah mengalami keluhan ada gangguan pada kesehatannya, padahal menjadi lebih baik apabila sebelum keluhan itu timbul kesehatan lansia sudah di waspadai dan dicatat untuk dikawal lebih lanjut.

c. Dengan melihat faktor-faktor yang mempengaruhi kunjungan pasien di posbindu lansia tersebut perlunya diterapkan Pengembangan program Posbindu Lansia di wilayah kerja Kecamatan Ciputat dengan mengedepankan prinsip pencegahan pada lansia untuk mendukung kelancaran program pencegahan dan penanggulangan Penyakit Tidak Menular di kota Tangerang Selatan, dengan cara mengembangkan pola kerja posbindu lansia yang tepat sesuai kemampuan masyarakat lansia di daerah tersebut beserta keikut sertaan aspirasi masyarakat dan swasta.

\section{METODE PELAKSANAAN PKM}

Metode pelaksanaan kegiatan dalam melaksanakan solusi yang ditawarkan untuk mengatasi permasalahan yang ada:

1. Mengadakan pertemuan dengan tokoh agama, tokoh masyarakat dan perangkat posbindu untuk melakukan survei awal tentang kegiatan yang ada di posbindu. Apabila belum ada kader Posbindu Lansia hal ini menyebabkan Kepala Puskesmas terdekat atau Puskesmas keliling (apabila ada) diangkat sebagai Koordinator dan Penanggung Jawab. Pada keadaan ini puskesmas berperan ganda yaitu sebagai inisiator, evaluator sekaligus pelaku program sehingga dapat menyita banyak waktu mereka yang sebenarnya adalah melayani kesehatan masyarakat. 
2. Diadakan wawancara dengan Kepala Posbindu Jeruk untuk mengetahui adanya potensi, permasalahan dan tantangan Posbindu Lansia desa Cipayung untuk keberlangsungan Posbindu lansia. Juga diadakan wawancara tentang persepsi responden/ masyarakat untuk keberlangsungan Posbindu lansia di wilayah kecamatan Ciputat.

3. Pemetaan kondisi Posbindu Lansia yang sudah ada di kecamatan Ciputat, dengan mempelajari:

a. Konsep Posbindu Lansia yang ada di wilayah Kecamatan Ciputat Kota Tangerang Selatan, yang dikelompokkan dalam beberapa topik, antara lain Pengertian, Tujuan, sasaran Kegiatan, Wadah Kegiatan, Pelaku Kegiatan, Bentuk Kegiatan, Tipe Posbindu lansia di wilayah Puskesmas dan Kemitraan

b. Langkah-langkah Posbindu Lansia di wilayah Kecamatan Ciputat meliputi persiapan, kegiatan, pelatihan kader posbindu, pencatatan, kegiatan tenaga pelaksana posbindu setiap bulan

c. Pelaksanaan Posbindu Lansia di wilayah Kecamatan Ciputat yang meliputi: waktu penyelenggaraan, tempat dan pelaksanaan kegiatan, peran berbagai pihak, pembiayaan pelaksanaan posbindu lansia, pencatatan dan pelaporan, Tindak lanjut hasil Posbindu lansia serta Rujukan Posbindu lansia.

d. Pembinaan Posbindu Lansia secara periodik di wilayah Kecamatan Ciputat.

4. Analisis dan penerapan konsep pelaksanaan posbindu lansia yang direncanakan sesuai dengan data yang didapatkan di posbindu lansia di wilayah Kecamatan Ciputat

\section{HASIL DAN PEMBAHASAN}

\section{Beberapa Hal yang Dapat di Lakukan Untuk Pengembangan Posbindu Lansia Jeruk:}

I. Konsep Posbindu Lansia

A. Wadah kegiatan

1. Anjuran mengadakan aktifitas fisik/olah raga Bersama, karena belum adanya kegiatan ini, yang seharusnya dapat dilakukan pada waktu penyelenggaraan Posbindu lansia, dilakukan rutin setiap minggu, dapat dilakukan di lapangan atau halaman rumah warga

2. Kegiatan rujukan ke Puskesmas sudah harus dilakukan dengan pemanfaatan penanganan pra-rujukan.

\section{B. Pelaku Kegiatan}

1. Sumber daya manusia untuk Posbindu Jeruk masih sangat terbatas, kader masih terbatas melakukan penimbangan dan pengukuran tekanan darah. Untuk itu kami mengadakan pelatihan penggunaan alat test kadar gula darah kepada para kader, sekalian menyumbang alat tersebut kepada posbindu.

2. Sarana pendukung kegiatan masih belum diberikan oleh atasan yang membawahi Posbindu Jeruk, sehingga 5 meja yang seharusnya disiapkan untuk kegiatan posbindu masih belum terpenuhi. Untuk itu kami berinisiatif memnuhi jumlah meja yang diperlukan sehingga kegiatan dapat berjalan dengan lancar.

\section{Bentuk Kegiatan}

1. Perlunya dilakukan pengukuran lingkar perut untuk mengetahui lemak visceral

2. Perlunya pengukuran kadar gula darah yang dapat dilakukan oleh para kader

\section{Ada beberapa pelayanan Posbindu PTM Dasar yang belum dilaksanakan, meliputi:}

1. Dengan menggunakan instrumen untuk identifikasi riwayat PTM dalam keluarga dan yang telah diderita sebelumnya, misalnya kadar gula darah 
2. perilaku berisiko

3. potensi terjadinya cedera dan kekerasan dalam rumah tangga,

4. Pengukuran lingkar perut dan Indeks massa tubuh (IMT)

5. Dengan instrumen untuk identifikasi analisa lemak tubuh,

6. Pemeriksaan uji fungsi paru sederhana

7. Penyuluhan mengenai pemeriksaan payudara sendiri

Tujuh hal diatas belum dilaksanakan dalam posbindu Jeruk sehingga kami melakukan penyuluhan kesehatan tentang hal tersebut agar mereka dapat meneruskan kepada warga lansia

\section{E. Kemitraan}

1. Perlunya kemitraan dengan Laboratorium Klinik swasta dan asuransi kesehatan untuk mendukung implementasi dan pengembangan kegiatan, misalnya yang disebut dengan kegiatan Prolanis (Program Pelayanan Penyakit Kronis) kerjasama dengan BPJS, a.1:

a. Program Promotif berupa Penyuluhan diberikan sebulan sekali

b. Program Preventif berupa Senam Kesehatan Jasmani diberikan seminggu sekali

c. Program Kuratif /Pemeriksaan bekerjasama dengan Laboratorium Klinik Swasta dilaksanakan secara insidentil, atau melalui rujukan

2. Kemitraan dengan Pusling (Puskesmas Keliling) dan Pustu (Puskesmas Pembantu) untuk komunikasi dan koordinasi. Kemitraan ini dapat dibuat dengan cara pembagian jadwal kunjungan ke desa di sekitarnya

\section{Langkah-Langkah Posbindu PTM}

\section{A. Persiapan, bekerjasama dengan:}

1. Puskesmas memulai rangkaian kegiatan antara lain:

a. Melakukan pertemuan koordinasi dengan kelompok potensial yg bersedia membantu penyelenggarakan Posbindu lansia

b. Mempersiapkan sarana, tenaga di Puskesmas dalam menerima rujukan dari Posbindu lansia

c. Mengumpulkan data dan informasi besaran masalah PTM, sarana-prasarana pendukung dan sumber daya manusia.

2. Puskesmas pembantu melakukan kegiatan:

a. Memberikan informasi dan sosialisasi tentang PTM kepada masyarakat lansia

b. Mengidentifikasi kelompok masyarakat yang mempunyai faktor resiko PTM dan penyakit lainnya

c. Melakukan rujukan ke puskesmas bagi peserta yang mempunyai gejala sesuai dengan syarat rujukan

3. Puskesmas Keliling melakukan kegiatan:

d. Memberikan informasi dan sosialisasi tentang PTM pada 10 desa di wilayah puskesmas Kertasemaya

e. Mengidentifikasi kelompok masyarakat yang mempunyai faktor resiko PTM dan penyakit lainnya

f. Melakukan rujukan ke puskesmas bagi peserta yg mempunyai gejala sesuai dengan syarat rujukan 


\section{B. Pelatihan Kader Posbindu lansia}

Belum adanya pelatihan Kader Posbindu lansia padahal jumlah kader sangat terbatas di Posbindu lansia di lingkungan desa Cipayung

\section{Pencatatan}

1. Utk pencatatan hasil pelaksanaan Posbindu lansia Jeruk dapat disiapkan kartu menuju sehat Faktor Risiko Penyakit Tidak Menular (KMS FR-PTM) dan buku pencatatan.

2. Untuk mendukung kegiatan edukasi dan konseling disiapkan media KIE misal serial buku pintar untuk pelaksana, lembar balik, leaflet, brosur, model makanan (foodmodel) dan lainnya

3. Pencatatan yang sudah lengkap kemudian dapat dilakukan pelaporan ke bagian UKM Pengembangan di bagian pelayanan kesehatan lansia Puskesmas setempat.

\section{Kegiatan Tenaga Pelaksana Posbindu lansia setiap bulan}

1. Pada bulan awal setiap tahun dapat dibuat laporan kepada pimpinan wilayah desa akan diadakan Posbindu lansia di desa tsb dengan pelaksana pustu, pusling atau dibantu bidan desa dan kader posyandu yang ada dimasing masing daerah

2. Menyiapkan sarana dan menyusun rencana dan jadwal kerja per bulan selama setahun

3. Memberikan informasi kepada sasaran, melakukan wawancara, pemeriksaan dan pencatatan,

4. Melakukan rujukan apabila diperlukan

5. Melaksanakan konseling kepada pesertadengan faktor resiko PTM

6. Melaksanakan kegiatan aktifitas fisik/olah raga bersama.

7. Membangun jejaring kerja dengan stake holder pelaksana

8. Melakukan konsultasi dengan petugas puskesmas, pustu dan pusling

\section{E. Pelatihan Kader Posbindu lansia}

Belum adanya pelatihan Kader Posbindu lansia secara reguler, sehingga kader Posbindu lansia di lingkungan desa Cipayung sebatas meengerjakan pengukuran tekanan darah

\section{F. Kegiatan Tenaga Pelaksana Posbindu lansia setiap bulan}

1. Pada bulan awal setiap tahun pihak posbindu lapor kepada pimpinan wilayah desa akan diadakan kegiatan Posbindu lansia di desa tersebut dengan pelaksana pustu, pusling dibantu bidan desa dan kader posyandu yang ada dimasing masing daerah

2. Menyiapkan sarana dan menyusun rencana dan jadwal kerja per bulan selama setahun

3. Memberikan informasi kepada sasaran, melakukan wawancara, pemeriksaan dan pencatatan,

4. Melakukan rujukan apabila diperlukan

5. Melaksanakan konseling kepada peserta dengan faktor resiko PTM

6. Melaksanakan penyuluhan berkala secara terjadwal

7. Melaksanakan kegiatan aktifitas fisik/olah raga bersama.

8. Membangun jejaring kerja dengan stake holder pelaksana

9. Melakukan konsultasi dengan petugas puskesmas, pustu dan pusling 


\section{G. Kegiatan Posbindu}

1. Belum adanya program senam lansia seminggu sekali dan kegiatan kemitraan dengan Laboratorium Klinik swasta dan asuransi kesehatan oleh peserta posbindu.

2. Para Pemangku Kepentingan antara lain Camat, Lurah/Kepala Desa Tokoh/Penggerak Masyarakat, dunia Usaha harus berperan serta mendukung penyelenggaraan Posbindu PTM dalam bentuk sarana dan pembiayaan

\section{H. Tindak lanjut hasil Posbindu lansia}

1. Pada tahap awal, kondisi faktor risiko Penyakit Tidak Menular dapat dicegah dan dikendalikan antara lain dengan :

a. diet sehat, aktifitas fisik/olah raga cukup dan gaya hidup sehat seperti berhenti merokok

b. pengelolaan stres dll.

c. Melalui konseling dan edukasi dengan kader konselor/edukator,

d. Meningkatkan pengetahuan dan keterampilan masyarakat dalam mencegah dan mengendalikan faktor risiko Penyakit Tidak Menular

2. Untuk mendapatkan perawatan lebih lanjut, Puskesmas bisa merujuk ke RS Swasta dan Pemerintah. Rujukan di posbindu Jeruk, untuk mendapatkan perawatan lebih lanjut, diposbindu Jeruk belum ada aturan merujuk ke RS

3. Kegiatan aktifitas fisik/olah raga bersama, dapat dilakukan pada waktu penyelenggaraan Posbindu lansia, dilakukan rutin setiap minggu di lapangan atau halaman rumah warga.

4. Pelaksanaan studi banding untuk meningkatkan pengetahuan dan kemampuan tenaga pelaksana sampai saat ini belum dilakukan di Posbindu lansia wilayah Cipayung. Hal ini sangat penting untuk dilakukan karena sangat bermanfaat untuk para peserta Posbindu Jeruk.

\section{KESIMPULAN DAN SARAN}

Pengembangan Posbindu Lansia Jeruk telah dilaksanakan, diharapkan akan terbentuk:

1. Penyediaan sarana pelayanan kesehatan: berupa pemberdayaan masyarakat desa dalam bidang kesehatan melalui posbindu lansia, agar masyarakat lansia bisa hidup mandiri dalam menolong dirinya sendiri, tenaga kesehatan ditingkatkan kualitasnya dalam rangka pencegahan serta peningkatan penyuluhan di bidang kesehatan dalam rangka penanggulangan penyakit tidak menular

2. Peningkatan kepedulian pola hidup sehat: melalui sosialisasi cara hidup bersih dan sehat, masyarakat umum dan lansia diajak untuk berpartisipasi penuh karena pola hidup bersih dan sehat telah dikembangkan pada tingkat kecamatan hingga desa, dengan cara antara lain membentuk Pokja desa sehat. Dengan demikian promosi kesehatan dan pencegahan terutama terhadap penyakit tidak menular akan semakin giat dilakukan

3. Keterlibatan masyarakat lansia pada program untuk sosialisasi kesehatan diharapkan berkembang pada program pemerintah lainnya seperti Desa Siaga/Gerakan Masyarakat Mandiri Sehat (GEMMAS), Hijau dan Bersih lingkunganku, Senam lansia, senam Germas, Kegiatan Prolanis dan kegiatan lain yang terkait.

4. Melanjutkan atau menghidupkan kembali semangat untuk hidup sehat sehingga angka harapan hidup meningkat 


\section{Ucapan Terima Kasih (Acknowledgement)}

Ucapan Terima kasih kami tujukan kepada LPPM UPN Veteran Jakarta, warga dan anggota Posbindu Jeruk dan para kader yang telah bekerjasama dengan baik dalam pelaksanaan PKM ini.

\section{REFERENSI}

Anggraeni 2014, Hubungan antara Kinerja Kader Posyandu Lansia terhadap Kepuasan Lansia Di Kelurahan Rempoa Wilayah Binaan Kerja Puskesmas Ciputat Timur, Skripsi, Terpublikasi, UIN Syarif Hidayatullah, Jakarta.

Atika Febriyani, 2016. Hubungan antara peran kader dengan tingkat kehadiran lansia di posyandu lansia wilayah kerja Puskesmas Kesesi I Kabupaten Pekalongan. Naskah Publikasi Program Studi Ners Sekolah Tinggi Ilmu Kesehatan Muhamaddiyah Pekajangan Pekalongan

Badan Pusat Statistik Jawa Barat. (2014). "Jawa Barat Dalam Angka 2014." jabar.bps.go.id.

Badan Perencanaan Pembangunan Nasional United Nation Population Fund, 2013. Proyeksi Penduduk Indonesia 2010-2035.

Badan Pusat Statistik. (2014). "Statistik Penduduk Lanjut Usia."

Badan Pusat Statistik, 2016. Indeks Pembangunan Manusia. https://www.bps.go.id/subjek/view/id/26

Depkes RI. (2013) Triple Burden Ancam Lansia.www.depkes.go.id/article/view/13100008/tripleburden-ancam-lansia.html Depkes RI (2014) Situasi dan Analisis Lanjut Usia.http://www.depkes.go.id/article/view/14010200005/download-pusdatininfodatininfodatin-lansia.html Dinas Kesehatan Sulawesi Selatan

Erpandi, (2013). Posyandu Lansia. Jakarta: Penerbit Buku Kedokteran EGC

Handayani, D. E., 2012. Pemanfaatan Pos Pembinaan Terpadu Oleh Lanjut Usia di Kecamatan Ciomas Kabupaten Bogor Tahun 2012 dan Faktor Yang Berkaitan. [Online] Available at: http://lib.ui.ac.id [Accessed 28 Juli 2016].

Kementerian Kesehatan RI. (2010). Pedoman Pembinaan Kesehatan Lanjut Usia Bagi Petugas Kesehatan. Jakarta, Direktorat Bina Kesehatan Komunitas Kementrian Kesehatan RI.

Kementerian Kesehatan RI. (2013). www.depkes.go.id. "Gambaran Kesehatan Lanjut usia di Indonesia.".

Nasution, Z., 2013. Pengaruh pengetahuan, sikap, dukungan keluarga dan kader terhadap pemanfaatan posyandu lanjut usia di wilayah kerja puskesmas Bandar Dolok kecamatan Pagar Merbau Kabupaten Deli Serdang. [Online] [Accessed Juli 2016].

RI, K. K., 2010. Pedoman Pembinaan Kesehatan Lanjut Usia Bagi Petugas Kesehatan. Jakarta: Direktorat Jendral Bina kesehatan Masyarakat.

Riskesdas, 2013. www.depkes.go.id/resources/download/general/Hasil\%

Telaumbanua, N., 2012. Pengetahuan dan sikap lansia tentang pemanfaatan pelayanan posyandu lansia di Kelurahan Pasar Teluk Dalam Kabupaten NIAS SELATAN.[Online] [Accessed Juli 2016].

WHO. (2010). Global Recommendation On Physical Activity For Health. whqlibdoc.who.int/publications/2010/9789241599979_eng.pdf?ua=1

Widya, A., 2015. Analisis Faktor Yang Mempengaruhi Pemanfaatan Posyandu lansia di Kecamatan Kolang, Kabupaten Tapanuli Tengah Tahun 2015. [Online] [Accessed Juli 2016]. 